\title{
MINERAL RESOURCE POTENTIAL OF THE CLARION RIVER ROADLESS AREA, ELK COUNTY, PENNSYLVANIA
}

\author{
By \\ Stanley P. Schweinfurth and Wallace deWitt, Jr., U.S. Geological Survey \\ and \\ Robert A. Welsh, Jr. and Paul T. Behum, U.S. Bureau of Mines \\ 1983
}

Studies Related to Wilderness

Under the provisions of the Wilderness Act (Public Law 88-577, September 3, 1964) and related acts, the U.S. Geological Survey and the U.S. Bureau of Mines have been conducting mineral surveys of wilderness and primitive areas. Areas officially designated as "wilderness," "wild," or "canoe" when the act was passed were incorporated into the National Wilderness Preservation System, and some of them are presently being studied. The act provided that areas under consideration for wilderness designation should be studied for suitability for incorporation into the Wilderness System. The mineral surveys constitute one aspect of the suitability studies. The act directs that the results of such surveys are to be made available to the public and be submitted to the President and the Congress. This reports presents the results of a mineral survey of the Clarion River Roadless Area (09022), Allegheny National Forest, Elk County, Pa. The area was classified as a further planning area during the Second Roadless Area Review and Evaluation (RARE II) by the U.S. Forest Service, January 1979.

\section{MINERAL RESOURCE POTENTIAL SUMMARY STATEMENT}

The Clarion River Roadless Area, hereinafter called the study area (fig. 1), comprises 4,042 acres in the southeasternmost part of the Allegheny National Forest, Elk County Pa. The Federal Government owns about 89 percent of the surface rights in the study area. The remaining surface rights and all of the subsurface rights are privately owned.

The study area is deemed to have a high potential for natural gas, a low potential for oil, a low potential for coal and construction materials, and no potential for metallic-mineral deposits. Gas currently is the most important mineral resource in the study area. As of 1982, the National Fuel Gas Supply Corp. operated five producing gas wells within the study area. The gas is produced from Upper Devonian sandstone beds in the Ridgway gas field. Additional gas resources may exist in untested or unstimulated sandstone beds of the Upper Devonian and in deeper strata. Although the Ridgway gas field is nearly depleted, it may have future utility as a gas-storage field.

A small amount of coal is probably present in the study area. Although coal beds were not observed within the area, two coal beds thick enough to contain resource ${ }^{1}$ quantities of coal were observed nearby. Total original resources of coal in the study area are estimated to be about 1.3 million short tons (table 1 ). However, it is estimated that neither coal beds exceeds $28 \mathrm{in}$. in thickness in the study area so that neither coal bed may contain reserve base ${ }^{2}$ quantities of coal in the study area. The coal is tentatively ranked as high-volatile A bituminous; it is low in sulfur but has a high ash content.

Underclays and shales could be used in structural applications, such as floor and building brick or structural tile. Sandstone, sand, and gravel in the study area have been utilized locally for construction purposes but these deposits are of limited extent.

The conclusions presented in this report are based on geologic mapping, examinations of mines, quarries, and prospects, a study of gas and oil well stratigraphic and production data, and a geochemical survey of stream sediments and bedrock.

${ }^{1}$ Resource quantities include beds of bituminous coal $14 \mathrm{in.}$ or more thick that occur at depths to 6,000 $\mathrm{ft}$. (U.S. Bureau of Mines and U.S. Geological Survey, 1976).

2 Reserve base includes beds of bituminous coal $28 \mathrm{in}$. or more thick that occur at depths to 1,000 $\mathrm{ft}$. The reserve base includes coal from only the measured and indicated categories of reliability (U.S. Bureau of Mines and U.S. Geological Survey, 1976). 


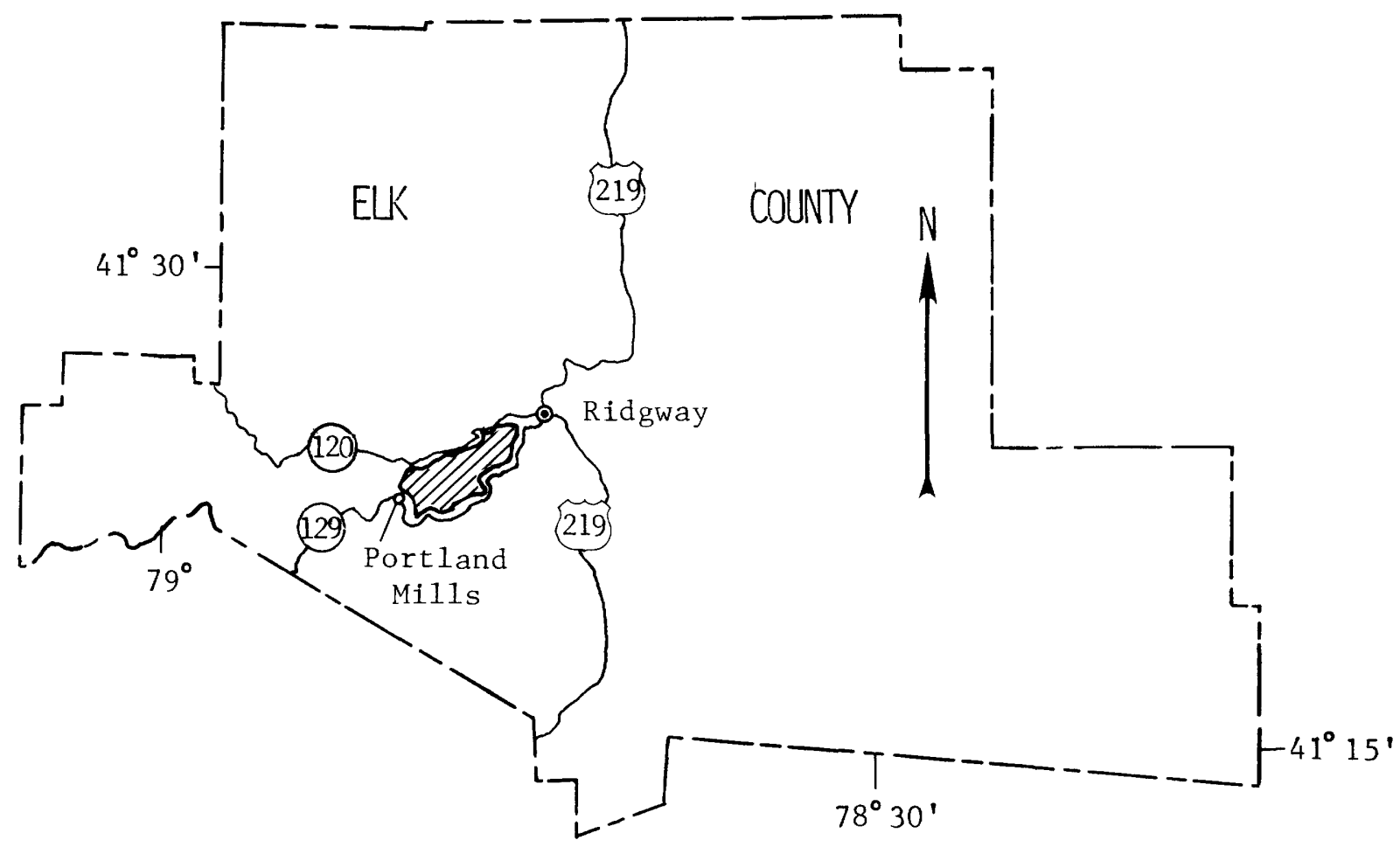

SCALE $1: 500,000$

10 10 20 MILES

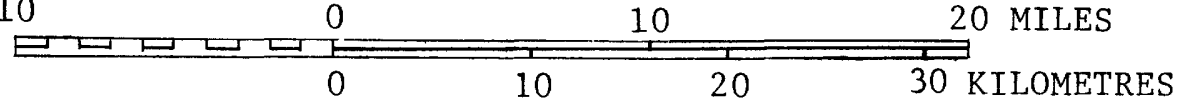

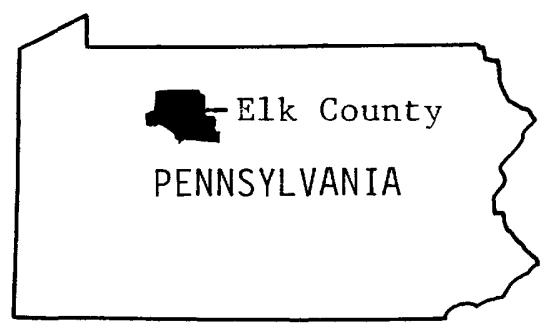

Figure 1.--Index map showing the Clarion River Roadless Area, (shaded), Allegheny National Forest, Elk County, $\mathrm{Pa}$. 
Table 1.-- Estimated original bituminous coal resources covered by less than $1,000 \mathrm{ft}$ of overburden in the Clarion River Roadless Area

(values in thousands of short tons, as of December 31, 1981)

\begin{tabular}{|c|c|c|c|c|}
\hline \multicolumn{5}{|c|}{ Original Resources } \\
\hline & & $\begin{array}{l}\text { Measured and } \\
\text { Indicated }\end{array}$ & Inferred & Total \\
\hline Formation & Coal bed & $\begin{array}{c}\text { In } \\
\text { beds } \\
14-28 \\
\text { inches } \\
\text { thick }\end{array}$ & $\begin{array}{c}\text { In } \\
\text { beds } \\
14-28 \\
\text { inches } \\
\text { thick }\end{array}$ & $\begin{array}{c}\text { In } \\
\text { beds } \\
14-28 \\
\text { inches } \\
\text { thick }\end{array}$ \\
\hline \multirow[t]{2}{*}{$\begin{array}{l}\text { Lower map } \\
\text { unit } 1\end{array}$} & e & 134 & 0 & 134 \\
\hline & c & 782 & 392 & 1,174 \\
\hline Total & & 916 & 392 & 1,308 \\
\hline
\end{tabular}

1 See accompanying map, figure 3 and Schweinfurth and others, 1982 . 


\section{INTRODUCTION}

The Clarion River Roadless Area (fig. 1), comprises 4,042 acres in the southeasternmost part of the Allegheny National Forest, Elk County, Pa. The study area lies about $1 \mathrm{mi}$ west of Ridgway, $\mathrm{Pa}$., and is accessible via State Routes 120 or 129 .

Physiographically, the study area lies within the slightly folded eastern part of the Kanawha Section of the Appalachian Plateaus Province (Fenneman, 1930). The plateau surface in the study area locally reaches an altitude of about $1,840 \mathrm{ft}$. Topographic relief ranges up to about $510 \mathrm{ft}$ and averages about $400 \mathrm{ft}$. The study area is near the northern edge of the Appalachian Region coal field.

\section{Past Investigations}

The geology of Elk County was described by Ashburner (1881; 1885) from field work performed between 1876 and 1879. Sisler (1932) published a detailed description of the bituminous coal fields of Pennsylvania, which included Elk County. Berg (1977) compiled a reconnaissance geologic map of the Hallton, $\mathrm{Pa}$. 15-minute quadrangle from field investigations and various other sources; this quadrangle includes the study area.

The subsurface geology of the region was investigated by the Pennsylvania Geological Survey for the U.S. Department of Energy's Eastern Gas Shales Project (Piotrowski and Harper, 1980). A report by Piotrowski (1981) on the Medina Group of Silurian age includes the study area. Additional commodityspecific reports that include the Elk County area discuss: 1) oil and gas (Fettke, 1950; Lytle and others, 1959 and 1961; Kelley and others, 1970; Kelley and Wagner, 1972; Lytle and Balogh, 1977); 2) bituminous coal (Ashley and others, 1928; Birge and others, 1963; Skema and others, 1975); and 3) clay (Shaw, 1927; Leighton, 1941; Williams, 1960).

\section{Present Investigation}

U.S. Geological Survey (USGS) investigations were conducted by Stanley P. Schweinfurth and Nelson L. Hickling in the fall of 1980 . Stratigraphic sections and coal beds were measured, altitudes of individual stratigraphic units, mines, and prospects were determined using an altimeter, and mappable units and the geologic structure were determined in and adjacent to the study area (Schweinfurth and others, 1982). Hickling, assisted by Schweinfurth, conducted geochemical investigations in October 1980 to test for indistinct or unexposed mineral deposits that might be recognized by their geochemical halos. Eighteen representative bedrock samples and 9 stream-sediment samples were collected and analyzed spectrographically for 31 elements, including the common metals having the greatest economic importance (Hickling and others, 1983). Wallace deWitt, Jr. evaluated the potential for gas and oil in the study area.

The U.S. Bureau of Mines (USBM) field reconnaissance was conducted by Robert A. Welsh, Jr. and Paul T. Behum in the spring and summer of 1980 . Thirty rock samples and 7 samples of coal were collected from outcrops in and near the study area. Rock samples were analyzed for 40 elements by semiquantitative spectrographic analysis at TSL Laboratories, LTD., Spokane, Wash. Radiometric, Xray fluorescence, induction-coupled plasma, and atomic-absorption analyses were performed on selected samples. Clay and shale samples were subjected to preliminary ceramic and bloating tests by the USBM Tuscaloosa Research Center, Tuscaloosa, Ala. Coal analyses were performed by the U.S. Department of Energy (DOE), Division of Solid Fuel Mining and Preparation, Coal Analysis Laboratory, Pittsburgh, $\mathrm{Pa}$. Details of the analyses performed on samples collected by USGS personnel were reported by Welsh and Behum (1982). Industry representatives, consultants, and the oil and gas divisions of the Pennsylvania Geological Survey and the New York State Department of Resouces were contacts regarding the gas and oil potential of the study area.

\section{Acknowledgments}

The authors thank Paul D. Brohn, who was District Ranger, Ridgway District, U.S. Forest Service, at the time the field work was done, for information on sandstone quarries within the study area. We appreciate also the information provided by Wayne Leeper, formerly of the National Fuel Gas Supply Corp. (NFGC) and Lamont Beers, of NFGC, who provided gas-well locations for the study area, and Chuck Lindahl, of Benjamin Coal Company, who gave information on that company's former strip mine near Lake City, Pa.

Arthur A. Socolow and Thomas M. Berg of the Pennsylvania Geological Survey, Harrisburg, Pa., provided guidance on the geology of northwestern Pennsylvania, and John A. Harper of the Pittsburgh office of the Pennsylvania Geological Survey provided data on oil- and gas-well records.

\section{SURFACE- AND MINERAL-RIGHTS OWNERSHIP}

The Federal Government owns about 89 percent of the surface rights in the study area. The remaining surface rights and all of the mineral rights are privately owned (fig. 2). Third-party mineral rights, covering 99 percent of the study area, are reserved by National Fuel Gas Supply Corp. A right-of-way for a telephone line cuts across the western side of the study area along Little Bear Creek.

\section{GEOLOGY}

About $540 \mathrm{ft}$ of sedimentary rocks of the Lower(?) Mississippian and the Lower(?) and Middle(?) Pennsylvanian series crop out in the study area (accompanying map fig. 3), and about 13,000 or 14,000 $\mathrm{ft}$ of older Paleozoic sedimentary rocks may be present in the subsurface (Harris, 1975).

The basal part of the exposed stratigraphic section consists of as much as $280 \mathrm{ft}$ of continental and marine, fine- to coarse-grained clastic rocks which are here assigned to the Cuyahoga(?) Formation and underlying Knapp(?) Formation undivided of the Lower(?) Mississippian Series. These formations are not subdivided in this report because the boundary between the two formations appears to be gradational and because the entire sequence is poorly exposed in and near the study area. The Cuyahoga(?)-Knapp(?) unit is truncated by an erosional unconformity of regional extent (Edmunds and others, 1979, figs. 5, 7, and 8 ).

Overlying the unconformity is a sequence of alternating units of very coarse-grained, quartzose, clastic rocks and fine- to medium-grained clastic rocks that contain a few thin beds of coal (accompanying 


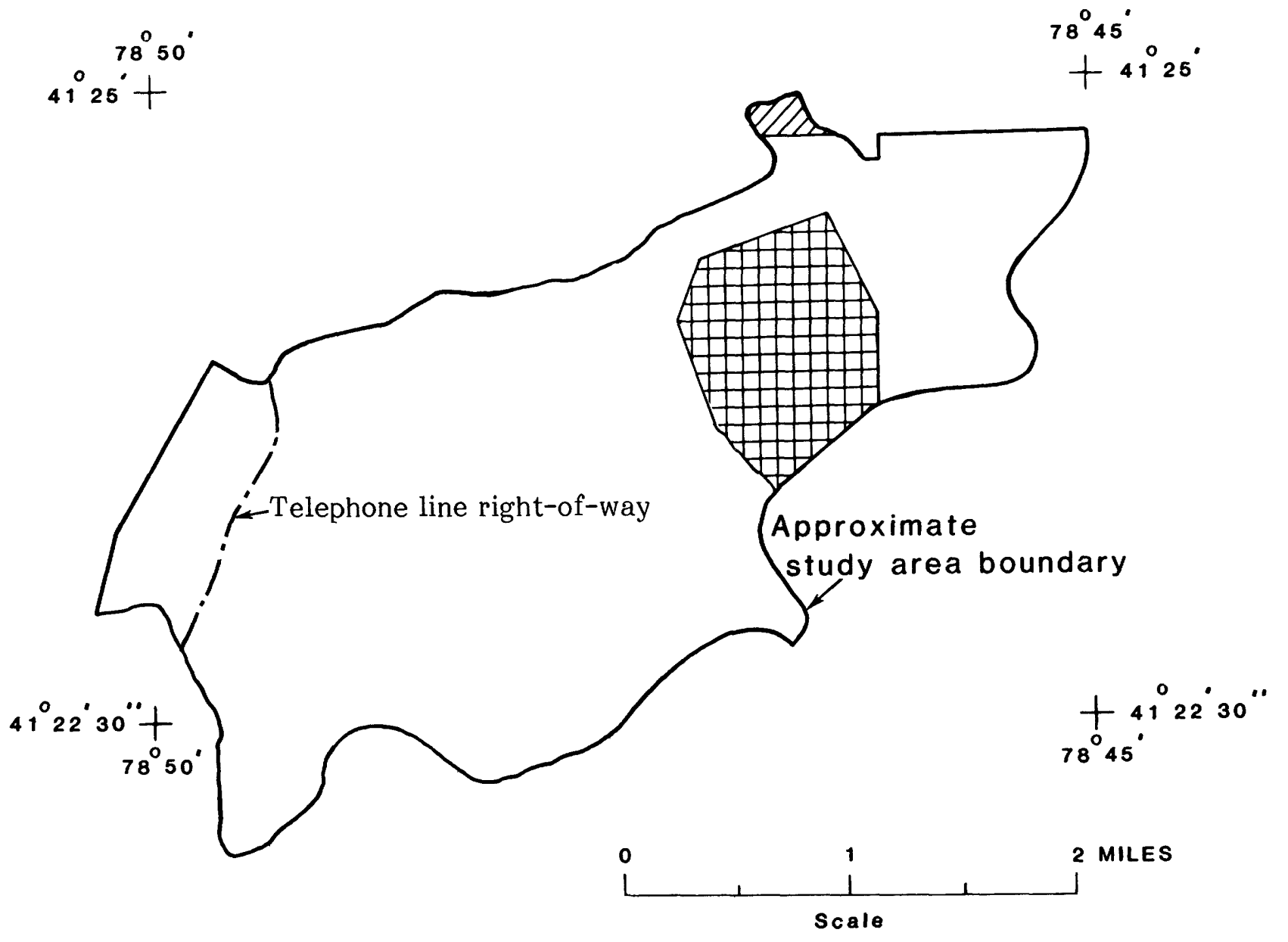

EXPLANATION

Minerals, oil and gas reserved by third party,

Federally owned surface

Minerals, oil and gas reserved by original owner,

Federally owned surface

Minerals, oil and gas outstanding,

privately owned surface

Figure 2.--Surface- and mineral-rights ownership. 
map, fig. 3). This sequence reaches a maximum thickness of about $260 \mathrm{ft}$ in the study area. The Pennsylvania Geological Survey (Berg, 1977; Edmunds and others, 1979, figs. 7 and 8; and Berg and others, 1980 ) assigns these rocks to the Pottsville Formation; however, because this sequence is lithologically dissimilar to the type Pottsville of eastern Pennsylvania (Wood and others, 1969, p. 70-78), the term Pottsville is not used in this report. Instead, mappable units in the sequence are identified informally as members 1 through 5 , in ascending order (accompanying map, fig. 3; Schweinfurth and others, 1982) because it was not feasible to extend the geologic work from the study area so as to make secure stratigraphic correlations with named stratigraphic units in other parts of northwestern Pennsylvania. This was also true for the coal beds observed near the study area; as a result the coal beds are identified by letters a through $\mathrm{g}$ in ascending order (accompanying map, fig. 3 ).

Unmapped deposits of colluvium mantle most valley slopes. Alluvium, consisting of unconsolidated clay, silt, sand, coarse gravel, and large boulders, underlies many valley floors. The study area is south of the southernmost extent of Pleistocene glaciation in this part of Pennsylvania.

The study area lies on the gently dipping southeast limb of the Johnson Run syncline (Berg, 1977), or the "Johnson Run (Fifth) Bituminous Coal Basin" (Ashburner, 1881). The axis of the syncline lies about $1.5 \mathrm{mi}$ northwest of the northwesternmost part of the study area and trends northeast. The strata in the study area dip about 25 to $30 \mathrm{ft}$ per mi to the northwest (Schweinfurth and others, 1982, fig. 4).

\section{ASSESSMENT OF MINERAL RESOURCE POTENTIAL}

Natural gas is the principal mineral resource in the study area. National Fuel Gas Supply Corp. operates five active gas wells in the study area, with production from the Ridgway Gas Field (Lamont Beers, NFGC, oral commun., 1982; fig. 3). Although the Ridgway field is nearing depletion, it could be used for gas storage. Additional gas, and possibly oil, may exist in untested or unstimulated horizons in the subsurface of the study area (Wayne Leeper, formerly of NFGC, oral commun., 1980).

Bituminous coal, clay and shale, sandstone, and sand and gravel have been produced near the study area and sandstone has been quarried in the study area. Resources of coal in coal beds c and e (table 1) have been estimated for the study area. Coal bed $g$ (accompanying map, fig. 3) was not observed near enough to the study area and resources were not estimated for the coal bed.

Preliminary evaluation of clay and shale indicates that they may be suitable for the manufacture of structural-clay products. The bedding characteristics and purity of sandstone within the study area are not consistent enough to permit uses of the sandstone for other than rough dimension stone. Sand and gravel deposits in the study area are of limited extent. Local construction needs for this material can be met by ample resources outside the study area. Metallic-mineral deposits were not identified during the study and none have been reported in the literature. Major chemical anomalies were not found by the geochemical survey (Hickling and others, 1983), and there is no evidence of a potential for metallic-mineral deposits in the study area.

\section{Gas and oil}

Of the approximately $14,500 \mathrm{ft}$ of Paleozoic sedimentary rock underlying the study area (Harris, 1975), the shallow sandstone beds of the Upper Devonian sequence (Kelley and others, 1970) appear to be the best reservoir rocks for both gas and oil (fig. 4). The study area has a high potential for natural gas in these beds of fine- to coarse-grained sandstones, which accumulated as offshore bars and beaches along the fringe of the large Catskill delta complex, as shown by wells in the Ridgway gas field in the eastern part of the study and other nearby gas fields (figs. 3 and 5). The study area has a low potential for oil, however, because the Upper Devonian rocks of the study area have been subjected to thermal-maturation temperatures near the upper limit for the generation and retention of oil (Epstein and others, 1977, p. 21). A small scattering of oil wells on the north side of the Ridgway gas field demonstrates that while some oil may be present in the Upper Devonian sandstone, significant accumulations of oil in these beds in the area is unlikely. Because thermal-maturation temperatures increase with depth of burial in unfaulted rock sequences, the underlying older Devonian rocks and Lower Paleozoic strata (fig. 4) have almost no potential for oil in the study area but are well within the thermal-maturation range for natural gas.

Drilling is the only method to confirm the presence of gas or oil in the Upper Devonian reservoir sandstone beds because they are lenticular, they are intercalated in a thick sequence of shaly source beds, and because the gas-productive porous and permeable zones are erratic in position within individual beds of sandstone. These conditions define the Upper Devonian reservoir beds as stratigraphic traps in which the extent and thickness of the reservoir depends upon changes in porosity and permeability in the reservoir developed during deposition or during consolidation and lithification of the sands. Stratigraphic traps are much more difficult to locate than structural traps because the position of a stratigraphic trap is rarely reflected in the configuration of the overlying bedrock.

The beds of shale that enclose the shallow Upper Devonian reservoir sandstone beds contain several percent organic matter-kerogen-which is the source material for gas and oil. The beds of greenishgray and gray shale are moderately good source beds, whereas the several zones of grayish-black and black shale in the Upper Devonian sequence and the Middle Devonian black Marcellus Shale (fig. 4) are richer in organic detritus and are better source beds. Where it is fractured by faulting, the Marcellus is both a source and a reservoir rock for natural gas in western Pennsylvania and adjacent New York, and is potentially gas productive under the study area. However, the characteristic low rate of productivity from fractured shale, the difficulty of locating and stimulating zones of fractures in the Marcellus Shale, and drilling depths of 5,000 to $6,000 \mathrm{ft}$ probably exclude it as a primary drilling target under existing economic conditions. It remains a good possibility as a secondary target, however, in exploratory tests primarily drilled to more deeply buried reservoir rocks. Gas has been produced from small pinnacle reefs to the north and nor theast of the study area in north-central Pennsylvania and adjacent New York from the Middle Devonian Onondaga Limestone (fig. 4), which is generally less than $100 \mathrm{ft}$ thick beneath 


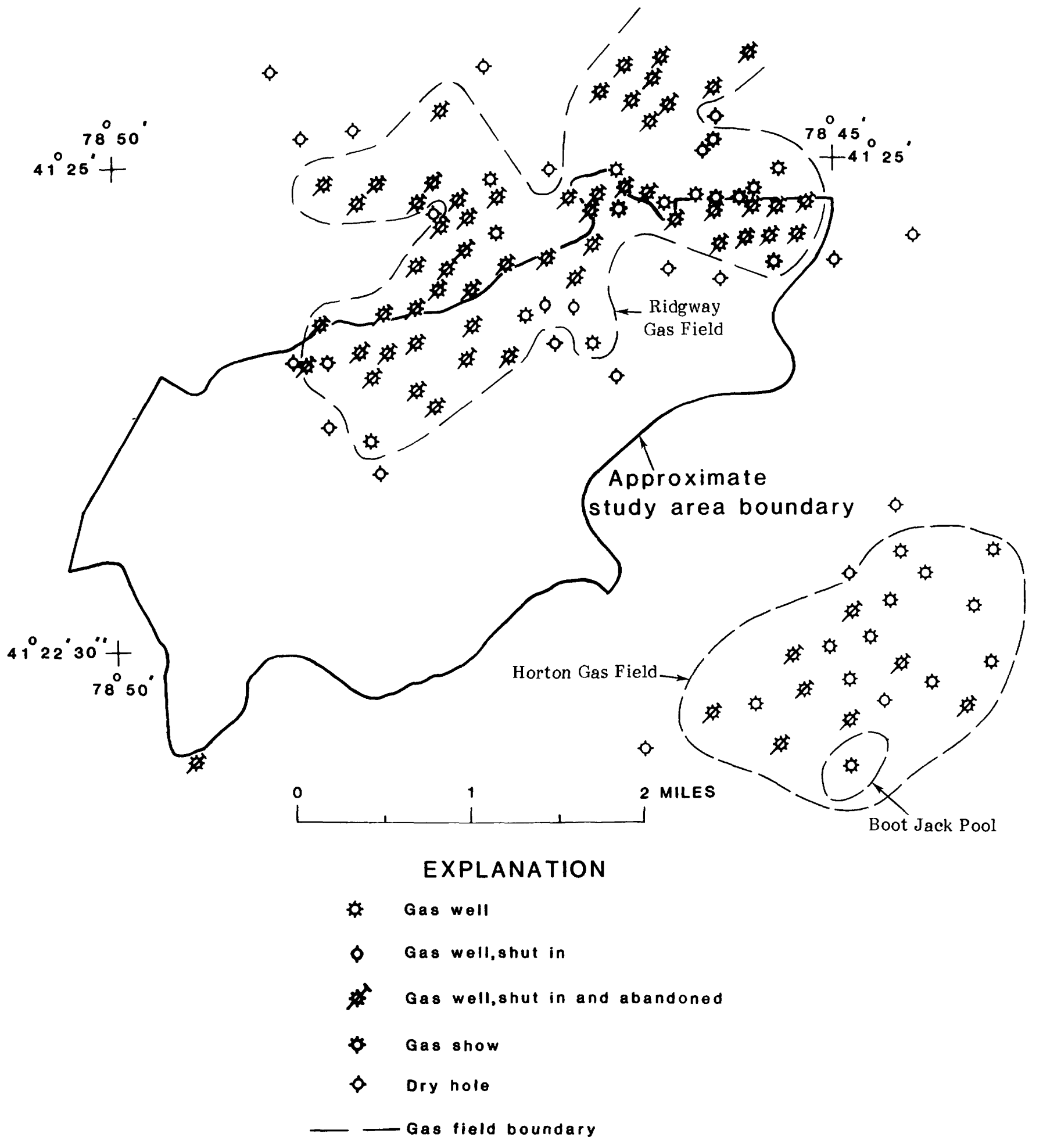

Figure 3.-Natural gas field and well locations. 


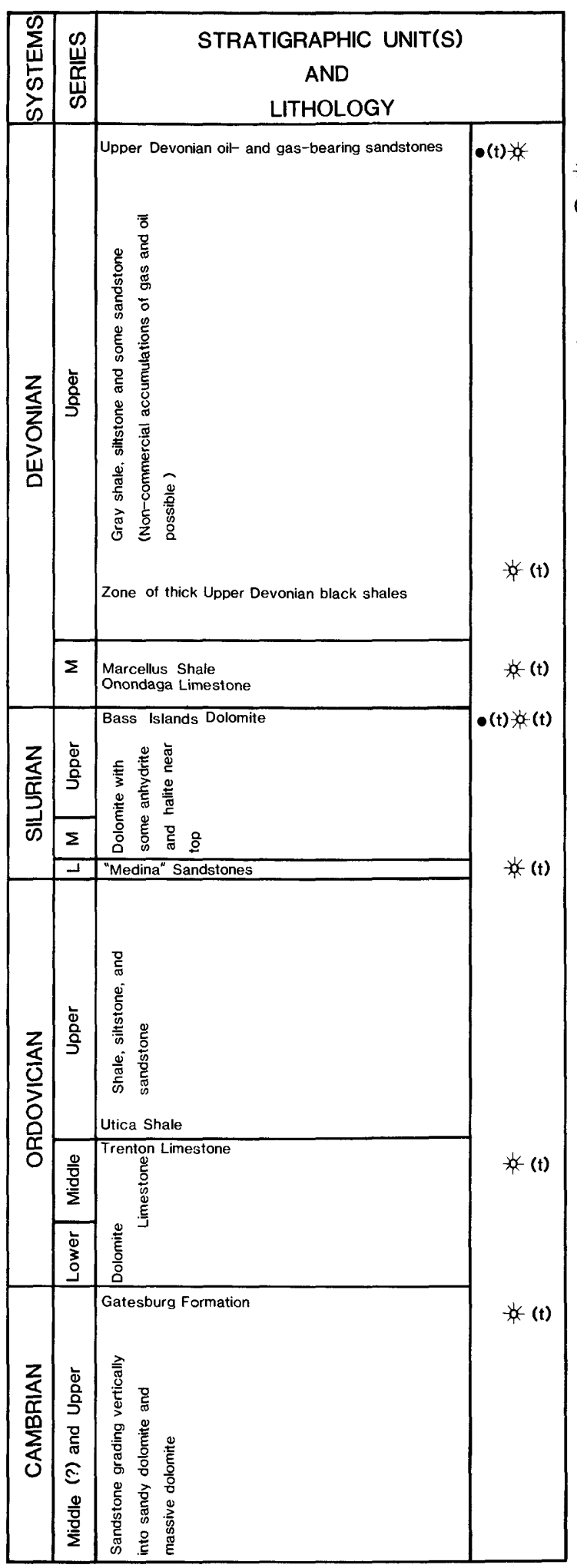

Explanation

- Oil production

Gas production

(t) Production but not within the limits of the Clarion River

Roadless Area

L Lower

M Middle

Figure 4.-Relative stratigraphic position of selected subsurface units beneath the Clarion River Roadless Area. 
the study area (Oliver and others, 1971). The reefs appear to be more abundant in New York, and the possibility of significant gas accumulation in an Onondaga reef beneath the study area seems remote.

The widespread, gas-productive Lower Devonian Oriskany Sandstone is absent beneath the study area (Cate, 1962). The absence of this well-known formation decreases the attractiveness of deep drilling in the study area. However, as much as 531 thousand cubic feet (MCF) per day of sour, hydrogen sulfidecontaining gas has been produced from the single-well Boot Jack Pool (Horton Field) about $2 \mathrm{mi}$ southeast of the study area (fig. 5) from the Bass Islands Dolomite, the uppermost unit in the Silurian sequence (figure 4). The Bass Islands was found to contain two smallvolume zones of gas and some salt water also in the Kane deep test, which was drilled about 13 mi north of the study area in 1928. The Boot Jack Pool and the Kane test suggest that the Bass Islands Dolomite may be gas productive beneath the study area.

Only a few deep tests have been drilled into and through the Silurian rocks in Elk County and adjacent counties during the past 100 years, and no deep drilling has been done in the study area. Only noncommercial volumes of gas were found in tests drilled to the basal Silurian sandstones, the "Medina sands" of drillers; however, because most of these wells were drilled before the introduction of well stimulation by hydraulic-fracturing techniques in the Appalachian basin, the possibility of gas resources in these tight, low permeability Silurian sandstones cannot be rejected.

Deep tests in Elk County have not penetrated more than $50 \mathrm{ft}$ into the Queeston Shale, the uppermost unit in the Ordovician sequence beneath the study area. Consequently, the potential for hydrocarbon accumulations in Ordovician and Cambrian rocks, which are approximately the lowermost $6,000 \mathrm{ft}$ of sedimentary rocks beneath the study area, is largely unknown in the vicinity of the study area.

A few deep and ultra-deep tests in western Pennsylvania and adjacent New York have penetrated the carbonate and quartzose rocks that comprise the greater part of the Ordovician and Cambrian sequence in the Appalachians. The Trenton Limestone (fig. 4), which is overlain by several hundred feet of moderately good source beds in the black Utica Shale, has been gas productive on the margin of the Appalachian basin in central New York adjacent to Lake Ontario. However, despite the nearby source beds, the Trenton does not appear to be gas-bearing down dip into north-central Pennsylvania in the vicinity of the study area.

Some of the deep tests that penetrated into or through the Cambrian rocks in western Pennsylvania found gas and oil in the Upper Cambrian Gatesburg Formation (fig. 4) in McKean and Crawford Counties (fig. 5). The Gatesburg is dominantly a dolomite, but it also contains beds and zones of sandstone, some of which are porous and permeable. However, salt water commonly occurs in close association with gas in the Gatesburg, and in the deep well nearest the study area, the Biery and Johnson \#1 Shaw drilled in southern Warren County, only salt water was found in a sandstone bed at the top of the Gatesburg.

These data on Ordovician and Cambrian rocks suggest strongly that there is a low potential for accumulations of gas in the lower half of the Paleozoic sedimentary sequence beneath the study area.
In summary, the Clarion River Roadless Area has a high potential for natural gas and a low potential for oil in the shallow Upper Devonian rocks, a moderate potential for natural gas in the Devonian and Silurian rocks, and a low potential in the Ordovician and Cambrian rocks. The potential for hydrocarbon accumulations in the Precambrian basement rocks is nil.

\section{Coal}

Approximately seven, thin, lenticular, nonpersistent coal beds occur in the Pennsylvania-age strata near the study area. These beds were not correlated with named beds outside of the study area, so they are referred to as coal beds a through $\mathrm{g}$ in this report (accompanying map, fig. 3; Schweinfurth and others, 1982). None of these coal beds were observed within the study area, but coal beds $c$ and e, which were observed just outside of the northeastern part of the study area, are locally thick and persistent enough to warrant projecting them into the northeastern part of the study area (accompanying map, figs. 7 and 8). However, neither bed is thick enough $(28$ in.) within the study area to contain reserve base 2 quantities and reserves of coal. Analyses of weathered samples from beds $\mathrm{c}$ and $\mathrm{e}$ (Welsh and Behum, 1982, table 3, sample numbers PCR-5, $-9,-11$, and -12 ) indicate that both beds are high in ash content (about 18 to 34 percent and about 20 to 33 percent, respectively, on an asreceived basis), and low in sulfur content ( 0.5 to 0.6 percent for both beds, on an as-received basis). Fresh samples of coal from these beds presumably would contain less ash and oxygen because weathering oxidizes the coal and infiltration of soil into fractures in the coal may be reflected as higher ash content in the proximate analysis (Yohe, 1958; Rees, 1966). The coal is tentatively ranked as high-volatile A bituminous (Welsh and Behum, 1982).

The approximate distribution of coal bed $\mathrm{c}$ is shown in figure 7 and that the coal bed e in figure 8 on the accompanying map; thicknesses shown are for coal only. Coal bed $c$ was mined for local use at one small, abandoned adit just outside the northeast corner of the study area, but no mines were observed in bed e either in or near the study area. The amount of coal removed from coal bed $\mathrm{c}$ was not estimated because past mining is considered negligible in the study area.

The amount of original coal resources in the study area in beds $c$ and e that are greater than 14 in. in thickness and under less than $1,000 \mathrm{ft}$ of overburden is estimated to be about 1.3 million short tons (table 1). Original resources in bed $c$ are estimated similarly to be about 1.2 million short tons and in bed $\mathrm{e}$ about 134,000 short tons. Three beds are thin and lenticular; the Surface Mining Control and Reclamation Act of 1977 (30 U.S. Code, 1272 (e)) prohibits surface mining of coal on the Federal lands in national forests.

\section{Construction materials}

Underclay and shale associated with coal beds $f$ and $g$ (accompanying map, fig. 3 ) have been mined in a pit $1.8 \mathrm{mi}$ east of the study area (Welsh and Behum, 1982, fig. 2, sample localities PCR-14 and -16). Both this pit and a pit owned by the Yingling-Martin Brick Company, located beside Rt. 219 about seven miles northeast of the study area, supplied raw material for local brick manufacturing. The Yingling-Martin Brick Company utilized Mississippian- and Pennsylvanian-age shale to produce common, face, and paving brick during the 1930's (Leighton, 1941). 


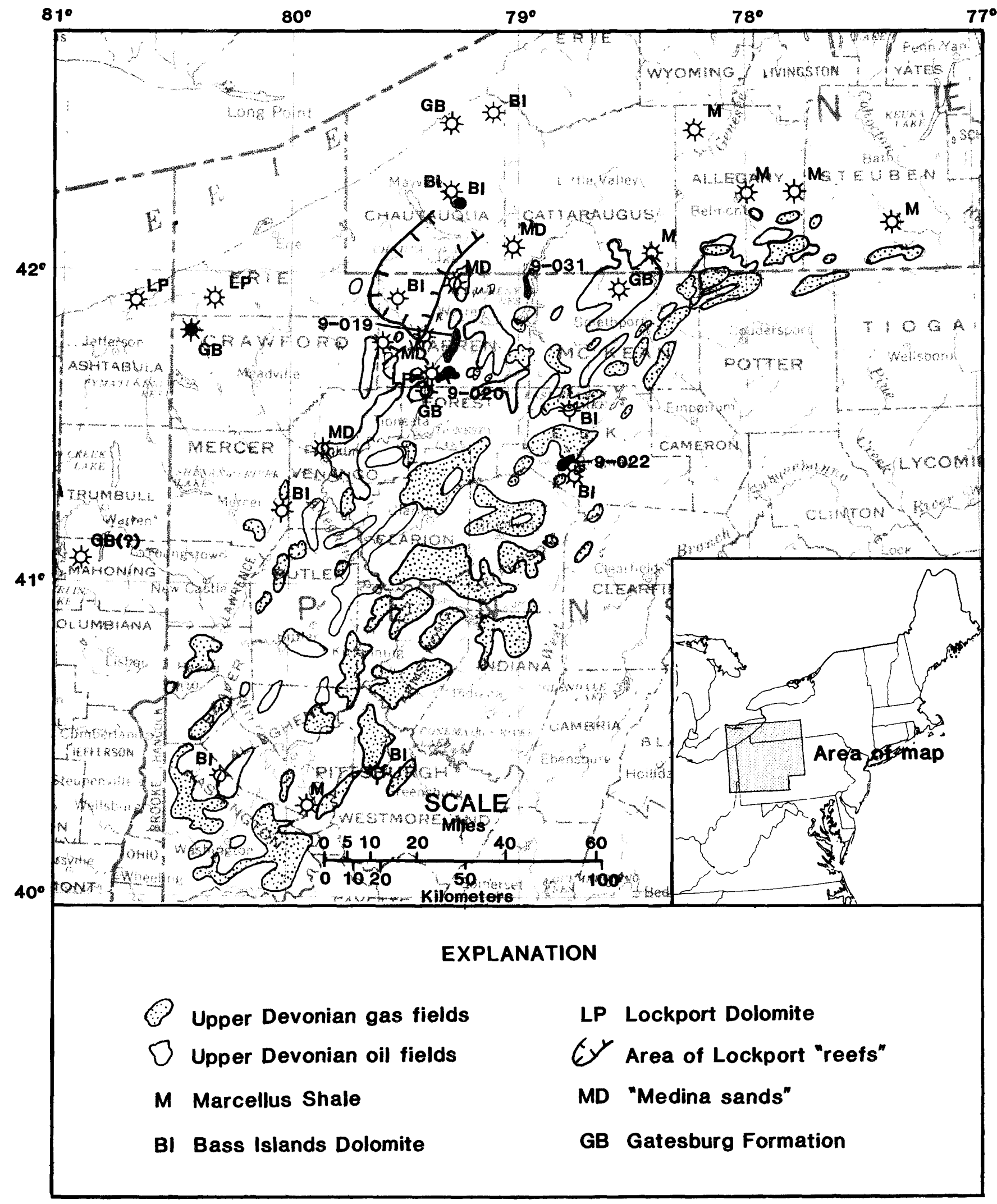

Figure 5.-Map showing the relationship of the Clarion River (9-022), Allegheny Front (9-019), Hickory Creek (9-020), and Cornplanter (9-031) Roadless Areas (solid black) to the oil and gas fields, wells, and exploratory tests discussed in the text. Production or significant shows from formations beneath the Upper Devonian reservoirs are shown by well symbols and block letters indicating individual formations. Well symbols are explained in figure 3; formations are given in figure 4. (The Allegheny Front and Hickory Creek Roadless Areas are the subject of a separate report by Schweinfurth and others, 1983; the Cornplanter Roadless Area is the subject of a separate report by Lesure and others, 1983.) 
Clay and shale units correlative with previously quarried units were sampled in and near the study area. Preliminary ceramic evaluations suggest potential structural-clay uses for clay in the study are (Welsh and Behum, 1982, table 5). All clay and shale samples tested were suitable for building-brick raw material. Two shale samples expanded during the preliminary bloating test, but these materials were too heavy for use in lightweight aggregate.

Atomic-absorption analysis of Pennsylvanianage underclay samples revealed a 30 percent average alumina content, and a sample of a Mississippian-age shale contained 38.5 percent alumina (Welsh and Behum, 1982, fig. 2, locality PCR-26). These alumina percentages are high in comparison to the average for clay or shale, and an alumina content this high has been regarded as a potential future alumina source (U.S. Bureau of Mines, 1967).

Sandstone has been quarried in the study area for construction, chemical, and foundry applications. Flaggv, olive-gray, Mississippian-age sandstone from an abandoned quarry in the northwest corner of the study area was used as road base material for Laurel Mill Road, built in the 1930's by the Civilian Conservation Corps (Paul Brohn, U.S. Forest Service, oral commun., 1980). In the 1920's, the Gardner Sand Company of Ridgway quarried and processed Pennsylvanian-age sandstone near the southeast corner of the study area (Welsh and Behum, 1982, fig. 2, sample site PCR-20). The sandstone product was used for chemical applications and as molding sand in steel foundries (Stone, 1928).

Pennsylvanian-age sandstone was used locally for rough building stone, as indicated by its presence in the abutments of a nearby abandoned railroad bridge over Big Mill Creek. However, because textural and bedding characteristics of these sandstones are generally irregular, their future use would probably be confined to rough dimension stone rather than architectural stone. In addition the iron-oxide content of the sandstone is too high for it to be used as a source of glass sand. Sandstone beds in the southeast part of the study area constitute a potential source of construction, rip-rap, and road-building material because of good access to the Baltimore and Ohio Railroad; however, abundant supplies of these materials are readily available elsewhere closer to markets.

Sand and gravel in alluvial deposits of the Clarion River have been used for construction material and molding sand for metal casting. An inactive sand and gravel pit across the Clarion River from the southwestern corner of the study area (Welsh and Behum, 1982, fig. 5) contains limited reserves. Gardner Sand and Gravel Company produced molding sand in the 1920 's from river-terrace deposits just south of the study area. The material was shipped by rail for use as molding sand in the casting of radiators, brake shoes, and other machinery (Stone, 1928). However, sand and gravel deposits in the study area are of limited extent, and larger and more accessible deposits exist elsewhere along the river.

An important constraint on the use of construction materials found in the study area is the cost of hauling raw materials considerable distances to be cleaned and processed.

\section{SELECTED REFERENCES}

Ashburner, C. A., 1881, Geological map of the central portion of Elk County, plate II in Ashburner, C.
A., 1885, The township geology of Elk and Forest Counties: Pennsylvania Geological Survey, Second Series, Report of Progress, v. RR, part II, p. 61-405.

1885, The township geology of Elk and Forest Counties: Pennsylvania Geological Survey, Second Series, Report of Progress, v. RR, part II, p. 61-405.

Ashley, G. H., Reese, J. F., and Sisler, J. D., 1928, Bituminous coal fields of Pennsylvania: Pennsylvania Geological Survey, Fourth Series, Bulletin M 6, pt. 4, 75 p.

Berg, T. M., 1977, Geologic map of the Hallton quadrangle, Pennsylvania: Pennsylvania Geological Survey, Fourth Series, Open-File Report, scale 1:62,500.

Berg, T. M., and others, 1980, Geologic map of Pennsylvania (1981): Pennsylvania Geological Survey, Fourth Series, Map 1, scale 1:250,000.

Birge, G. W., Wolfson, D. E., and Lynch, J. H., Jr., 1963, Carbonizing properties of coal from Elk, Clarion, Jefferson, Clearfield, and Centre Counties, Pennsylvania: U.S. Bureau of Mines Report of Investigation $6261,22 \mathrm{p}$.

Cate, A. S., 1962, Subsurface structure of the plateau region of north central and western Pennsylvania on top of the Oriskany Formation: Pennsylvania Geological Survey, Fourth Series, Map 9, scale $1: 250,000$.

Edmunds, W. E., and others, 1979, The Mississippian and Pennsylvanian (Carboniferous) Systems in the United States, Pennsylvania-New York, in The Mississippian and Pennsylvanian (Carboniferous) Systems in the United States: U.S. Geological Survey Prof essional Paper 1110-B, 31 p.

Epstein, A. G., Epstein, J. B., and Harris, L. D., 1977, Conodont color alteration - an index to organic metamorphism: U.S. Geological Survey Professional Paper 995, 21 p.

Fenneman, N. M., 1930, Physical divisions map of the United States (edition of 1946): U.S. Geological Survey, scale 1:7,000,000.

Fettke, C. R., 1938, The Bradford Oil Field, Pennsylvania-New York: Pennsylvania Geological Survey, Fourth Series, Bulletin M 21, $454 \mathrm{p}$.

1950, Summarized record of deep wells in Pennsylvania: Pennsylvania Geological Survey, Fourth Series, Bulletin M 31, 148 p.

Harper, J. A., and Piotrowski, R. G., 1978, Stratigraphy, extent, gas production and future gas potential of the Devonian organic-rich shales in Pennsylvania: Second Eastern Gas Shales Symposium, U.S. Department of Energy, Morgantown Energy Technology Center, Morgantown, West Virginia, Preprints (METC/SP78/6 v. 7), p. 310-329.

Harris, A. G., Harris, L. D., and Epstein, J. B., 1978, Oil and gas data from Paleozoic rocks in the Appalachian Basin-Maps for assessing hydrocarbon potential and thermal maturity (conodont color alteration isograds and overburden isopachs): U.S. Geological Survey Miscellaneous Investigations Series Map I-917-E, scale $1: 2,500,000$.

Harris, L. D., 1975, Oil and gas data from the Lower Ordovician and Cambrian rocks of the Appalachian basin: U.S. Geological Survey Miscellaneous Investigations Series Map I-917-D, sheet 2 , scale $1: 2,500,000$. 
Hickling, N. L., Schweinfurth, S. P., and Adrian, B. M., 1983, A reconnaissance geochemical survey of the Clarion River Roadless Area, Allegheny National Forest, Elk County, Pennsylvania: U.S. Geological Survey Open-File Report 83-22, 14 p.

Ingham, A. I., Lytle, W. S., Matteson, L. S., and Sherrill, R. E., 1956, Oil and gas geology of the Sheffield quadrangle, Pennsylvania: Pennsylvania Geological Survey, Fourth Series, Bulletin M 38, 72 p.

Kelly, D. R., Lytle, W. S., Wagner, W. R., and Heyman, Louis, 1970, The petroleum industry and the future petroleum province in Pennsylvania, 1970: Pennsylvania Geological Survey, Fourth Series, Mineral Reosurces Report M 65, p. 32-34.

Kelly, D. R., and Wagner, W. R., 1972, Surface to Middle Devonian (Onondaga) subsurface stratigraphy part I: Pennsylvania Geological Survey, Fourth Series, Open-File Report 1, 15 p.

Leighton, Henry, 1941, Clay and shale resources in Pennsylvania: Pennsylvania Geological Survey, Fourth Series, Mineral Resource Report M 23, $245 \mathrm{p}$.

Lesure, F. G, deWitt, Wallace, Jr., and Welsh, R. A., Jr., 1983, Mineral resource potential map of the Cornplanter Roadless Area, Warren County, Pennsylvania: U.S. Geological Survey Miscellaneous Field Studies Map MF-1510-C, scale 1:24,000.

Lytle, W. S., 1974, Oil and gas developments in Pennsylvania in 1973: Pennsylvania Geological Survey, Fourth Series, Progress Report 187, p. 18,41 .

Lytle, W. S., Bergsten, J. M., Cate, A. S., and Wagner, W. R., 1959, Oil and gas developments in Pennsylvania in 1958: Pennsylvania Geological Survey, Fourth Series, Progress Report 155, p. 6.

Lytle, W. S., Bergsten, J. M., Cate, A. S., Fairall, V. M., Heeren, L. A., and Wagner, W. R., 1961, A summary of oil and gas developments in Pennsylvania 1955 to 1959: Pennsylvania Geological Survey, Fourth Series, Bulletin M 45, $133 \mathrm{p}$.

Lytle, W. S., and Balogh, L. J., 1977, Maps of the oil and gas fields, natural gas pipelines, and oil pipelines of Pennsylvania: Pennsylvania Geological Survey, Fourth Series, Map 3, scale $1: 250,000$.

Oliver, W. A., Jr., deWitt, Wallace, Jr., Dennison, J. M., Hoskins, D. M., and Huddle, J. W., 1971, Isopach and lithofacies maps of the Devonian in the Appalachian basin: Pennsylvania Geological Survey, Fourth Series, Progress Report 182, scale 1 in. = approximately $20 \mathrm{mi}$.

Piotrowski, R. G., and Harper, J. A., 1980, Black shale and sandstone facies of the Devonian "Catskill" clastic wedge in the subsurface of western Pennsylvania: U.S. Department of Energy, Eastern Gas Shales Project series no. 13, 40 p.

Piotrowski, R. G., 1981, Geology and natural gas production of the Lower Silurian Medina Group and equivalent rock units in Pennsylvania: Pennsylvania Geological Survey, Fourth Series, Mineral Resource Report M 82, 21 p.

Rees, O. W., 1966, Chemistry, uses and limitations of coal analaysis: Illinois Geological Survey Report of Investigation $220,55 \mathrm{p}$.

Rickard, L. V., 1969, Stratigraphy of the Upper Silurain Salina Group-New York, Pennsylvania, Ohio, Ontario: New York State Museum and Science Service, Map and Chart Series No. 12.
Schmoker, J. W., 1980, Organic content of Devonian shale in western Appalachian Basin: American Association of Petroleum Geologists Bulletin v. 64 , no. 12 , p. 2156-2165.

Schweinfurth, S. P., Hickling, N. L., and Person, M. A., 1982, Geologic map of the Clarion River Roadless Area, Elk County, Pennsylvania: U.S. Geological Survey Miscellaneous Field Studies Map MF-1444-A, scale 1:50,000.

Schweinfurth, S. P., deWitt, Wallace, Jr., and Girol, V. P., 1983, Mineral resource potential map of the Allegheny Front and Hickory Creek Roadless Areas, Warren County, Pennsylvania: U.S. Geological Survey Miscellaneous Field Studies Map MF-1442-B, scale 1:50,000.

Secor, E. S., Larwood, G. M., Gupta, A. B., and Lees, A. S., 1977, Coal recovery from bituminous coal surface mines in eastern United Sates, a survey: U.S. Bureau of Mines Information Circular 8738, $14 \mathrm{p}$.

Shaw, J. B., 1927, Fire clays of Pennsylvania: Pennsylvania Geological Survey, Fourth Series, Bulletin M 10, 69 p.

Sisler, J. D., 1932, Bituminous coal fields of Pennsylvania, Part II-Detailed description of coal fields: Pennsylvania Geological Survey, Fourth Series, Mineral Resource Report M 6, 509 p.

Skema, V. W., Berg, T. M., Bragonier, W. A., Edmunds, W. E., Glass, G. B., Glover, A. D., Inners, J. D., and Sholes, M. A., 1975, Analyses and measured sections of Pennsylvania bituminous coals: Pennsylvania Geological Survey, Fourth Series, Mineral Resources Report 69, part II, p. 146-149.

Stone, R. W., 1928, Molding sands of Pennsylvania: Pennsylvania Geological Survey, Fourth Series, Bulletin M 11, p. 54 .

U.S. Bureau of Mines, 1967, Potential sources of aluminum: U.S. Bureau of Mines Information Circular 8335,148 p.

U.S. Bureau of Mines and U.S. Geological Survey, 1976, Coal resource classification system of the U.S. Bureau of Mines and U.S. Geological Survey: U.S. Geological Survey Bulletin 1450-B, 7 p.

Van Tyne, A. M., and Peterson, J. C., 1978, Thickness, extent of, and gas occurrences in Upper and Middle Devonian black shales of New York; Second Eastern Gas Shales Symposium: U.S. Department of Energy, Morgantown Energy Technology Center, Morgantown, West Virginia, Preprints (METC/SP-78/6 vol. I) v. 1, p. 99-127.

Welsh, R. A., Jr., and Behum, P. T., 1982, Mineral investigation of the Clarion River Rare II further planning area, Elk County, Pennsylvania: U.S. Bureau of Mines Open-File Report MLA 85-82, $32 \mathrm{p}$.

Williams, E. G., 1960, Relationship between the stratigraphy and petrography of Pottsville sandstones and the occurrence of high-alumina Mercer clay: Economic Geology, v. 55, no. 6, p. 1291-1302.

Wood, G. H., Jr., Trexler, J. P., and Kehn, T. M., 1969, Geology of the west-central part of the southern anthracite field and adjoining areas, Pennsylvania: U.S. Geological Survey Professional Paper 602, 143 p.

Yoke, G. R., 1958, Oxidation of coal: Illinois Geological Survey Report of Investigation 207, $51 \mathrm{p}$. 